DOI: $10.1515 / \mathrm{rpp}-2017-0007$

PhD in Pedagogical Sciences, Associate Professor, IRYNA ANDROSHCHUK

Khmelnytskyi National University

Address: 11 Instytutska St., Khmelnytskyi, 29016, Ukraine

E-mail: lemen77@ukr.net

$\mathrm{PhD}$ in Pedagogical Sciences, Associate Professor, IHOR ANDROSHCHUK

Khmelnytskyi National University

Address: 11 Instytutska St., Khmelnytskyi, 29016, Ukraine

E-mail: lemen77@ukr.net

\title{
PECULIARITIES OF FUTURE TECHNOLOGY TEACHERS' TRAINING IN POLAND AND GREAT BRITAIN
}

\begin{abstract}
The importance of studying foreign experience to enhance the efficiency of teacher training in higher education institutions has been justified. Peculiarities of future technology teachers' training in Poland and Great Britain have been considered. Special attention has been paid to revealing the ways of enhancing the level of teachers' professional competency while and after studying at university. The requirements for technology teachers' have been specified. It has been indicated that apart from the requirements for professional training, future specialists should follow moral rules, cooperate with the participants of the education process and manage information and communication technologies. Qualification categories of teachers in Poland as well as educational routes for future technology teachers' training in Great Britain have been found out. Based on the generalization of the study results, the authors have singled out the main cycles of professional disciplines needed for professional training of technology teachers' training in Great Britain. The role of school placements in future teachers' training for professional activity has been considered. It has been proved that the great amount of hours is allotted for practical training of students and forming of those skills and abilities needed in professional activity. Relative stages of students' practical training in higher education institutions have been identified.

Key words: technology teacher, pedagogical interaction, professional training, teaching qualification, training model, educational route, study program, education institution, education process.

\section{INTRODUCTION}

The reforming of secondary education makes appropriate adjustments to professional training of teachers and, in particular, technology teachers. Modern approaches in education suggest that future technology teachers should be able to organize cooperation with other members of the education process, collaborate with pupils, parents and colleagues; involve pupils in the creative process of making original and functional products during curricular and extracurricular activities; use innovative learning technologies focused on the harmonious personality development of each pupil and their professional identity. In addition, Ukraine's active integration in the European space requires the content and technologies of teachers' training to be reconsidered as they are guarantors of the younger generations' education. The efficiency of future specialists' training depends on their
\end{abstract}


readiness for pedagogical activity, professional competency. Therefore, it is necessary to study foreign experience in training future technology teachers, in particular, Polish and British achievements, to analyze and determine the main directions of improving the national education system.

\section{THE AIM OF THE STUDY}

The aim of the study is to generalize Polish and British experience in training technology teachers and consequently implement its positive aspects in the national education system.

\section{THEORETICAL FRAMEWORK AND RESEARCH METHODS}

Analysis of psychological and pedagogical research results demonstrates the significant interest among scholars and researchers in teacher training abroad. In particular, the international experience in training teachers in different foreign countries has been covered in scientific works of native researchers: in Great Britain - N. Bidyuk, Yu. Kishchenko, A. Parinov, O. Stelmashchuk; in France - M. Skorobogatova, B. Vulfson; in Germany - T. Koval, H. Lukianiuk, O. Rodina; in the USA - I. Gavrysh, T. Kapeliushna, Ya. Kolybabiuk, T. Koshmanova, Yu. Krasylnyk, R. Roman; in Poland - K. Binytska, T. Brodziński, M. Frejman, S. Frejman, M. Jakowicka, S. Kwiatkowski, R. Monko, R. Pasichnyk, G. Rua et al. However, insufficient attention is paid to technology teachers' training in Poland and Great Britain.

During theoretical study of the defined problem we have used the complex of theoretical methods, namely, explanatory and analytical method with using analysis and synthesis of scientific researches on technology teachers' training; methods of generalization and systematization - to highlight the peculiarities of teachers' professional training and formulate relevant conclusions.

\section{RESULTS}

Taking into account territorial proximity and a significant number of Ukrainian students obtaining education in Poland, there is a need to study Polish experience in training future technology teachers.

The problems of technology teachers' training in Poland have been covered in the researches of such Polish researchers as Z. Dambrowski, W. Furmanek, A. Marshałek, T. Nowacki, Ch. Pochanke, R. Polny, S. Szajek, V. Zarzecka and others. All the scholars agree that these teachers must have profound psycho-pedagogical, technical knowledge and skills. The training of future specialists is comprehensive in order to provide students with employment opportunities not only in education but also research administration, economics, industry. However, the training ia carried out not only within a higher education institution but also after graduation: during school placements under the supervision of experienced pedagogues, professional self-development.

The increasing level of professional competency contributes to teachers' professional development with corresponding increase in wages: teacher-trainee; contract teacher; appointed teacher; certified teacher; professor of education - a title of honour (Kwiatkowski, 2001). According to the Teacher's Charter, there are the following qualification categories: teacher-trainee; contract teacher; appointed teacher; diploma teacher (Kancelaria Sejmu, 2008). The transition from one category to another demonstrates teacher's professional growth and pedagogical mastery enhancement.

General training and development of technology teachers in Poland is subject to the principle of "addition - complication - actualization". At the same time, the emphasis is put on the integration of technical and informative components of technology teachers' training content. Rather significant are student research activities during training, enhancing 
their self-study and practical orientation toward professional training. Therefore, the education process is constructed so as to not overload students and let them independently choose the directions for self-development.

The results of analysis of curricula in technology teachers' training prove learning individualization, providing opportunities for independent choice of subjects, allotting significant number of hours for self-study. It should be noted that teachers provide students with a so-called indivudal support. This allows to implement the personality-oriented approach in training future technology teachers. Therefore, it is important that teachers should be able to organize pedagogical interaction with all the participants of the education process.

School placement plays an important role in professional training of technology teachers. Future specialists are to not only organize and conduct the education process, monitor its results in order to adjust their actions, but also to interact with colleagues, pupils and their parents. Usually, such placements last 8 weeks. However, depending on the institution, they can be appointed either for first or second year of study (Монько, 2010).

The reforming of education in Poland has made appropriate changes to the requirements for technology teachers and graduates of higher education institutions. Future technology teacher should be able to rationally consider the conditions of the education process organization in schools, develop and implement their own didactic strategy based on the interdisciplinary approach, organize and direct pupils' cognitive activity, create appropriate conditions for their creativity (Brodziński, Rua, 2002).

It must be noted that one of the requirements for teacher is to respect the principles of personal morality, be able to compromise (Jakowicka, 2008). It is important that teacher should be able to talk with pupils, perceive them, control their own emotions and behaviour; understand that mistakes and failures in the education process are life patterns that can be rectified only if one is willing to improve oneself (Frejman, Frejman, 2008).

Rather interesting in the context of our study is British experience in training future technology teachers. Thus, the complex nature of technology teachers' training is reflected in such documents as the "Teacher's Standards", "Competences for Design and Technology Teachers". This can be explained by the peculiarities of Design and Technology programmes of study, that are taught in schools and combine the following components: technologies, traditional crafts, types of designs, information technology, basic electronics, home economics and business. Over $12 \%$ of the total time load is devoted to this subject.

Design and Technology Teaching is based on the integrated design technology and provides for active involvement of pupils in research activities while conducting experiments, solving difficult situations. Consequently, this requires appropriate training of technology teachers who are to teach pupils to work not only with hand tools but also produce quality products. It should be mentioned that pupils should be able to previously plan the stages of production based on understanding of the interconnection between technological, ecological and aesthetic systems. In addition, they should monitor this process to further evaluate its efficiency and product quality. Therefore, one of the requirements for technology teacher is their readiness for pedagogical interaction, because only cooperation allows to involve pupils in creative activities, implement individual trajectory of learning for each pupil, encourage them to attend additional lessons, participate in events dedicated to Design and Technology and undergo extracurricular training (practice at mini-companies).

Summarizing British experience in training technology teachers, we can single out three models of their professional training: parallel, sequential and alternative. We would like to consider the content of each. 
The parallel model is used in training KS 1 and KS 2 technology teachers in teacher colleges. It is the most common model at universities of Great Britain. This model allows to obtain a Bachelor of Science degree in 3 years.

The sequiential model is used in art and techhology teacher colleges and universities at faculties of education. After completing the study, graduates obtain the Postgraduate Certificate in Education (PGCE).

The alternative model of professional training involves the implementation of such innovative programs as distance learning, flexible learning options, fast-track degrees, certified teachers (Стельмащук, 2012).

Within the implementation of these models, the system of professional training includes various educational routes to obtain the corresponding profession. In particular, these are:

1. Obtaining Postgraduate Certificate in Education (PGCE) at universities mainly. The duration of study is one year.

2. Obtaining Bachelor of Education that allows to gain Qualified Teacher Status (QTS). The study may last 3 or 4 years.

It should be mentioned that there are various alternative study programs for teachers. Foe instance, these include:

1) School Centred Initial Teacher Training (SCITT) that ensures active cooperation of all the units of education taking into account modern trends;

2) the Fast Track programmes that allow students to gain Qualified Teacher Status (QTS);

3 ) employment-based routes that provide relevant training in a certain field (for people over the age of 24) (Орехова, Полунина, 2007).

The presence of various study programmes that provide training by different paths allows to take account individual peculiarities of students and reveal their creative potential.

Technology teacher training in higher education institutions of Great Britain is based, primarily, on the formation of practical skills and abilities of personal and professional self-development. Generaly, such training involves the study of four basic cycles of courses:

1) professionally-oriented courses;

2) teaching-oriented courses;

3) practice-oriented courses;

4) school placements.

Thus, the main focus is put on school placement which takes about $25 \%$ of the total load time as an important component of teacher training. Professional training of teachers is characterized by close cooperation with higher education institutions. Teaching practice can be divided into the following stages: 1) intial; 2) introduction to professional activity; 3) professional growth; 4) generalization and systematization of the experience obtained; 5) teachers' professional development. Students may attend several schools and have their achievements assessed by class teacher, tutor and mentor. This three-pronged interaction of student with tutor and mentor allows school placement to become integrated and complete, thereby increasing its efficiency (Стельмащук, 2008). Special attention is paid to individual-typological and personal qualities and characteristics of future teacher.

It is important that professional growth of teacher continues after graduation as there are various study programs for certified specialists.

\section{CONCLUSIONS}

So, the study of Polish and British experience in future technology teachers' training allows to conclude that their level of professional competency and personal 
qualities is based on high education standards. Professional training is not completed after graduation and lasts all professional life. It has been found that, firstly, future technology teachers' training is carried out comprehensively to widen opportunities for further employment. Secondly, school placement plays a significant role in psychological, pedagogical and practical training of future specialists. Thirdly, schools and universities closely cooperate with each other. Fourthly, the education process is based on the personality-oriented approach as it allows to take into account the individual characteristics of each student and encourage the development of their creativity. The mentioned above can be used to improve future technology teachers' training.

Rather perspective for further researches we consider analysis of teacher training content abroad to single out its main directions and implement them in the national education system.

\section{REFERENCES}

1. Brodziński, T., Rua, G. (2002). Edukacja ogólnotechniczna w szkołach ogólnokształcacych [General Technical Education in Comprehensive Schools]. Zielona Góra : Praca zawód rynek pracy, 210 p. (in Polish).

2. Frejman, M., Frejman, S. (2008). O rozwijaniu refleksyjnej postawy przyszłych nauczycieli [The Development of Future Teachers' Reflective Attitudes]. In: Muchacka, B., Szymański, M. Nauczyciel w świecie współczesnym [Teacher in the Modern World]. Kraków : Impuls, 186 p. (in Polish).

3. Jakowicka, M. (2008). Nauczyciel $w$ ksztal ceniu i doskonaleniu $w$ kontekscie reformy edukacji [Teacher in Education and Development in the Context of Education Reform]. Warszawa : Wyd. Eurydice, 219 p. (in Polish).

4. Kancelaria Sejmu. (2008). Ustawa z dnia 6 grudnia 2007 r. o zmianie ustawy Karta Nauczyciela [The Amendment to the Act on Teacher's Charter as of December 6, 2007]. Poznan : Oficynf Ekonomiczna Wydawnictwa, 52 p. (in Polish).

5. Kwiatkowski, S. (2001). Kształcenie zawodowe. Dylematy teorii i praktyki [Professional Training. Dilemmas of Theory and Practice]. Warszawa : IBE, 153 p. (in Polish).

6. Монько, Р. М. (2010). Підготовка майбутнього вчителя «техніки» у Республіці Польща [Future “Technology" Teachers' Training in the Republic of Poland]. Tрудова підготовка учнів та студентів. Наукові записки. Серія: Педагогіка [Occupational Training of Pupils and Students. Scientific Notes. Series: Pedagogy], No 1, pp. 167-170 (in Ukrainian).

7. Орехова, Е. Я., Полунина, Л. Н. (2007). Подготовка учителей в современной Европе: учеб. пособие [Teachers' Training in Modern Europe: textbook]. Тула : Изд-во Тульского. гос. пед. ун-та им. Л. Н. Толстого, 182 р. (in Russian).

8. Стельмащук, О. 3. (2012). Підготовка майбутніх учителів дизайну і технології у вищих навчальних закладах Великої Британії [Future Design and Technology Teachers' Training in Higher Education Institutions of Great Britain]. Abstract of Thesis for PhD. Тернопіль, 20 p. (in Ukrainian). 